\title{
Differential capacity of nitrogen assimilation between apical and basal leaf portions of a tank epiphytic bromeliad
}

\author{
Cassia A. Takahashi, Gregório C.T. Ceccantini and Helenice Mercier* \\ Departamento de Botânica, Universidade de São Paulo, Caixa Postal 11461, 05422-970 São Paulo, SP, Brasil. *Corresponding \\ author:hmercier@usp.br
}

Received: 20 March 2007; Returned for revision: 17 May 2007; Accepted: 02 August 2007

\begin{abstract}
The leaf is the main organ of the vegetative body of tank epiphytic bromeliads, which may be subdivided into apical and basal parts. Little is known about the existence of morphological, anatomical or physiological differences between these two leaf portions. The objective of this study was to verify the existence of a differential capacity to assimilate nitrogen from urea between basal and apical leaf portions of Vriesea gigantea, a tank epiphytic bromeliad. Plants were cultivated in vitro in the presence of $5 \mathrm{mM}$ urea for 15 days. During this period, the activities of the enzymes glutamine synthetase (GS, EC 6.3.1.2) and NADH-dependent glutamate dehydrogenase (NADH-GDH, EC 1.4.1.2) were quantified, as well as the densities of trichomes and stomata found at the leaf surface of both regions. The highest activities of GS and NADHGDH were always detected at the top portion, and on the $3^{\text {rd }}$ day of in vitro cultivation an increase in these activities was detected. An inverse correlation between number of trichomes and stomata in these two leaf portions was verified: the top region presented $30 \%$ less trichomes and twice as many stomata as the basal region. This suggests that the upper region of the leaf may be preferentially involved with the assimilation of nitrogen from urea via GS and NADH-GDH, whereas the basal region may be involved with its absorption. This is the first study to report that ammonium assimilation may take place preferentially in a specific portion of tank-forming bromeliad leaves.
\end{abstract}

Keywords: Bromeliaceae, glutamate dehydrogenase, glutamine synthetase, stomata, trichome, urea

Capacidade diferencial de assimilação de nitrogênio entre as porções foliares basal e apical em bromélias epífitas com tanque: A folha é o principal órgão do corpo vegetativo das bromélias epífitas com tanque, podendo ser subdividida em pelo menos duas porções distintas: apical e basal. Muito pouco se conhece acerca da existência de diferenças morfológicas, anatômicas ou fisiológicas entre essas porções. O objetivo deste estudo foi comparar a capacidade de assimilação do nitrogênio, proveniente da uréia, entre as porções basal e apical em folhas de Vriesea gigantea, uma bromélia epífita com tanque. Para tanto, plantas dessa espécie foram cultivadas in vitro na presença exclusiva de uréia (5 mM) como fonte de nitrogênio, por 15 dias. Durante esse período, quantificaram-se as atividades das enzimas sintetase da glutamina (GS) (EC 6.3.1.2) e desidrogenase do glutamato dependente de NADH (NADH-GDH) (EC 1.4.1.2), além das densidades de tricomas absorventes e estômatos encontrados nas superfícies foliares de ambas as regiões. As maiores atividades de GS e NADH-GDH sempre foram detectadas na porção apical, sendo que, no $3^{\circ}$ dia de cultivo in vitro, houve um máximo de atividade. Constatou-se uma correlação inversa entre o número de tricomas e estômatos nessas duas porções foliares: a apical apresentou um menor número de tricomas (30\% menor) e uma maior quantidade de estômatos (o dobro) quando comparada com a basal. Sugere-se que a região apical estaria, preferencialmente, envolvida com a assimilação do nitrogênio proveniente da uréia via GS ou NADH-GDH, enquanto a basal, possivelmente, com a sua absorção. Este é o primeiro relato a relacionar uma determinada porção foliar, de uma bromélia com tanque, com a assimilação do amônio, preferencialmente, nessa estrutura.

Palavras-chave: Bromeliaceae, desidrogenase do glutamato, estômato, sintetase da glutamina, tricoma, uréia

Braz. J. Plant Physiol., 19(2):119-126, 2007 


\section{INTRODUCTION}

The family Bromeliaceae is distributed along the entire tropical and subtropical zones of the Americas, with South America being the main dispersion center (Leme and Marigo, 1993). The success of this wide geographic distribution may be explained by the acquisition of morpho-physiological specializations that enable these species to survive under different environmental conditions (Padilha, 1973). Depending on the life habits, bromeliads may be classified as terrestrial, rupestrian or epiphytic. In this latter case, they may be atmospheric or tank (Leme and Marigo, 1993).

Unlike terrestrial types, epiphytic bromeliads present quite a reduced root system, the main its function is to fix the bromeliad to the host plant. The absorption of water and nutrients occurs mainly through leaves, which are covered by absorbing trichomes, also known as scales (Benzing, 1990).

Most epiphytic bromeliads present leaves arranged around their short stem axis (rosette disposition) with an age gradient from the center leaves (younger) to the peripheral ones (older) and from the base to the top of each leaf. In addition, the rosette leaf arrangement creates an environment of variable light intensity as a result of the inclination angle of leaves, which decreases with leaf age, increasing its exposure to sunlight (Olivares and Medina, 1990). There is also the formation of a longitudinal light gradient in each leaf, where the apical region receives more light than the basal region during the entire life of the plant.

A partial superposition of the leaf bases occurs in the vast majority of bromeliads, forming what has been called a tank (Leme and Marigo, 1993). This structure is important for the storage of water and nutrients including organic compounds, such as amino acids, which may be absorbed by leaf trichomes (Benzing, 1990). The basal leaf portion is in contact with water and nutrients in the tank, while the apical region is located out of the tank region.

Studies showing the existence of morphological, anatomical or physiological differences between different regions of the same leaf in bromeliads are scarce. Sakai and Sandford (1980) studied trichomes in the leaf surface of Ananas comosus and observed that trichomes present at the top of leaves were less functional in absorption of water than those present at the base, since some trichome stalk cells appeared dead in the apical region of the leaf. Medina et al. (1994), using two cultivars of A. comosus, reported that increasing leaf age determined strong variations in nitrogen content. Furthermore, nitrogen concentration was higher in green leaf blades compared to non-photosynthetic tissues (leaf bases and stems). Popp et al. (2003) verified the existence of longitudinal gradients of organic acids and carbohydrates when quantifying these compounds in five leaf portions of some bromeliad species, detecting, for example, a higher sucrose concentration at the apical portion of pineapple leaves.

Some tank-forming epiphytic bromeliads were able to absorb and assimilate urea quite efficiently (Endres and Mercier, 2001a,b; Nievola et al., 2001). The nitrogen present in urea may become available to the plant metabolism when this compound is hydrolyzed by urease into $\mathrm{CO}_{2}$ and ammonium (Marschner, 1995). This ion may be incorporated into amino acids by the combined action of the enzymes glutamine synthetase (GS, EC 6.3.1.2) and ferredoxin-dependent glutamate synthase (Fd-GOGAT, EC 1.4.7.1) or by means of the enzyme NADH-dependent glutamate dehydrogenase (NADH-GDH, EC 1.4.1.2) (Miflin and Habash, 2002; Tercé-Laforgue et al., 2004). Urea has been considered an excellent source of nitrogen to stimulate the in vitro development of Vriesea gigantea, a tank-forming epiphytic bromeliad (Endres and Mercier, 2001a,b).

The objective of this study was to verify the existence of a differential capacity to assimilate nitrogen from urea between basal and apical leaf portions of leaves of $V$. gigantea. The plants that provided the leaves had been cultivated in vitro in the exclusive presence of this organic source of nitrogen. The activities of enzymes glutamine synthetase (GS) and glutamate dehydrogenase (NADH-GDH) were analyzed and correlated with the densities of stomata and trichomes present in the leaf surfaces of both apical and basal portions.

\section{MATERIAL AND METHODS}

Plant species and culture conditions: Vriesea gigantea Gaudichaud plants, species belonging to the class of 'tank epiphytic bromeliads', were obtained from in vitro germination of seeds, according to Mercier and Nievola (2003). After germination, the seedlings were transferred to a basic cultivation medium composed of macronu- 
trients from the Knudson formulation (Knudson, 1946) and micronutrients from the Murashige and Skoog formulation (Murashige and Skoog, 1962), in addition to $\mathrm{CaCO}_{3}$ at a concentration of $1 \mathrm{~g} \mathrm{~L}^{-1}$ (Salama and Wareing, 1979) (Figure 1). During the process of plant inoculation, the bases of bromeliad leaves were inserted into the semisolidified culture medium; therefore, the nutrients were permanently available for absorption through the foliar trichomes. The plants were maintained in this basic medium until reaching an average height of $3 \mathrm{~cm}$ (Figure 2 ). The in vitro cultivation as used here for nitrogen nutrition studies is an interesting strategy, as it eliminates the possibility that certain microorganisms might change the form of the nitrogen supplied to the bromeliads (Mercier et al., 1997).

The cultivation room had a photoperiod adjusted to $16 \mathrm{~h}$ with an average temperature of $26 \pm 2^{\circ} \mathrm{C}$. The light intensity at each shelf was $40 \mu \mathrm{mol}$ photons $\mathrm{m}^{-2} \mathrm{~s}^{-1}$.

Urea supply as the only nitrogen source: Bromeliads cultivated in vitro of approximately $3 \mathrm{~cm}$ height were transferred to the modified Knudson medium, i.e., without the addition of nitrogen salts, the objective being to deplete, at least in part, the endogenous nitrogen sources of the plant. The bromeliads remained in the nitrogen-free medium for one month and then were transferred into another medium which was modified to replace the original nitrogen sources by $5 \mathrm{mM}$ urea plus $1 \mathrm{~g} \mathrm{~L}^{-1} \mathrm{CaCO}_{3}, 0.64 \mathrm{~g} \mathrm{~L}^{-1}$ $\mathrm{CaSO}_{4}$ and $1 \mu \mathrm{mol} \mathrm{L}-1 \mathrm{NiCl}_{2} \cdot 6 \mathrm{H}_{2} \mathrm{O}$. The plants remained in this medium for 15 days. During this period, four harvests were carried out ( $1^{\text {st }}, 3^{\text {rd }}, 7^{\text {th }}$ and $15^{\text {th }}$ days $)$, always $5 \mathrm{~h}$ after the beginning of the light period in the cultivation room. Apexes and bases of bromeliad leaves were used (approximately $1 \mathrm{~cm}$ of each portion) (Figure 1).

Extraction of the enzymes GS and NADH-GDH: From a sample composed of 30 leaves, $0.5 \mathrm{~g}$ of fresh material was weighed and then macerated in a mortar with liquid nitrogen until a fine powder was obtained. This powder was transferred to centrifuge tubes previously cooled in liquid nitrogen; $4 \mathrm{~mL}$ of an extraction medium consisting of $0.05 \mathrm{M}$ imidazole buffer, $\mathrm{pH} 7.9$ and $5 \mathrm{mM}$ DTT was pipetted into each tube. These samples were submitted to two centrifugations at $10,000 \mathrm{~g}$ at $4{ }^{\circ} \mathrm{C}$, and the supernatant used to measure the activity of both enzymes (Cammaerts and Jacobs, 1985).

Analysis of GS activity: Glutamine synthetase activity was assayed based on the in vitro method proposed by Farnden and Robertson (1980) and Pérez-Soba et al. (1994), with modifications for $V$. gigantea. The total volume of the enzymatic reaction was $0.5 \mathrm{~mL}$ and included with $0.05 \mathrm{mM}$ imidazole buffer, $\mathrm{pH} 7.5,49 \mathrm{mM}$ hydroxylamine, $40 \mathrm{mM} \mathrm{MgCl}_{2}, 192 \mathrm{mM}$ glutamate and 50 $\mathrm{mM}$ ATP (pH 7.5), and $150 \mu \mathrm{L}$ of plant extract. The reaction began with the incubation of tubes at $30^{\circ} \mathrm{C}$ and was interrupted after $60 \mathrm{~min}$ by adding $1 \mathrm{~mL}$ of a solution containing $0.37 \mathrm{M}$ ferric chloride, $0.67 \mathrm{M} \mathrm{HCl}$ and $0.20 \mathrm{M}$

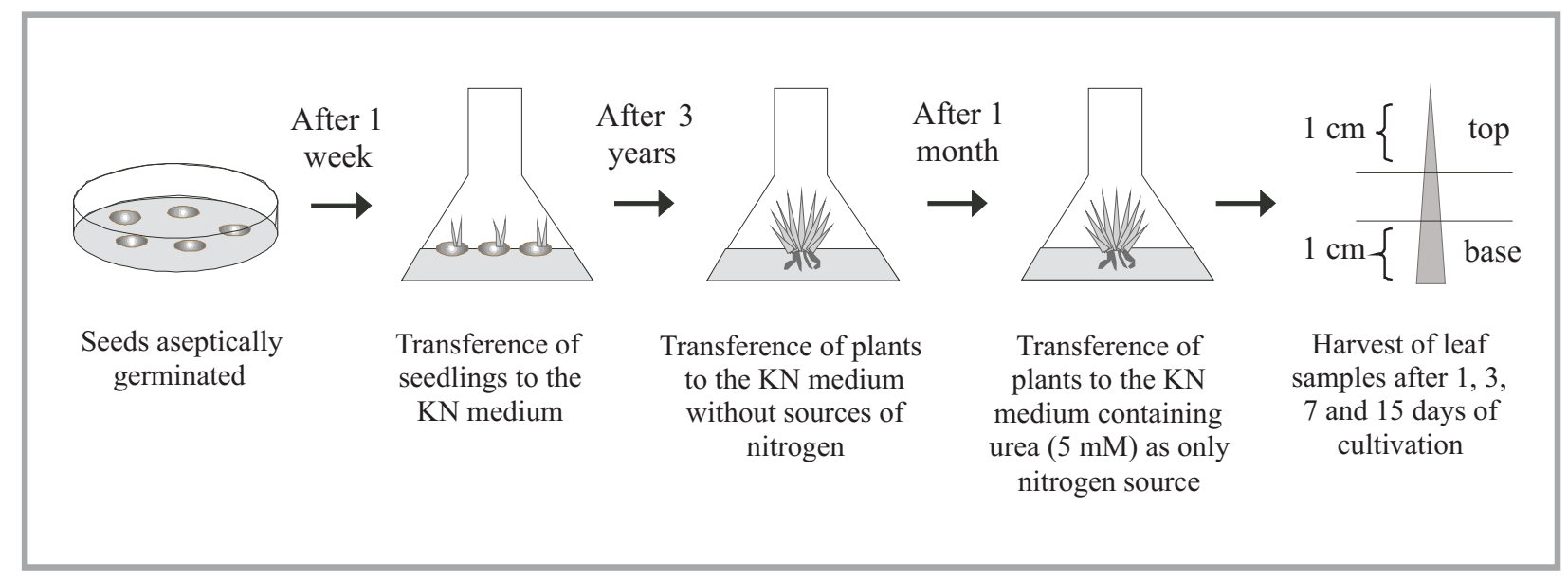

Figure 1. Scheme showing the in vitro cultivation of Vriesea gigantea plants in different media until the harvest of apical and basal leaf portions. $\mathrm{KN}=$ Knudson medium micronutrients and $\mathrm{CaCO}_{3}$ added. 


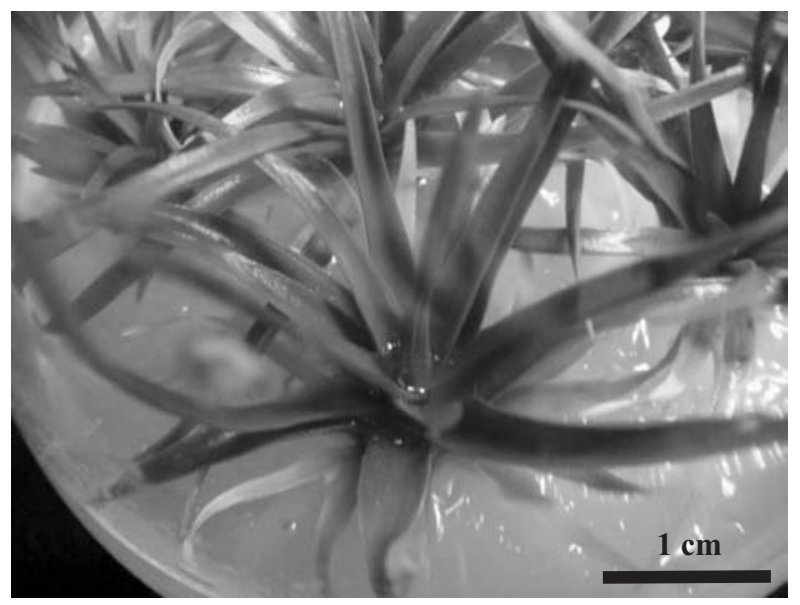

Figure 2. Vriesea gigantea plants cultivated in vitro on a semi-solid Knudson medium. Note that the tank region is well moistened.

trichloroacetic acid. The absorbances were read at 540 $\mathrm{nm}$. All of the assays were carried out in triplicate. The GS activity was expressed in nmol $\gamma$-glutamyl-hydroxamate produced per minute per gram fresh mass.

Analysis of the NADH-GDH activity: NADH-GDH was assayed according to Cammaerts and Jacobs (1985), with modifications for $V$. gigantea. The enzyme activity was quantified through the amount of NADH oxidized in the reaction. The total volume of the reaction was $3 \mathrm{~mL}$ and was composed of TRIS buffer $0.1 \mathrm{M} \mathrm{pH} 8.2,20 \mathrm{mM} 2-$ oxoglutarate, $150 \mathrm{mM}\left(\mathrm{NH}_{4}\right)_{2} \mathrm{SO}_{4}, 1 \mathrm{mM} \mathrm{CaCl}, 0.14 \mathrm{mM}$ $\mathrm{NADH}$, and $0.5 \mathrm{~mL}$ of plant extract. The reaction began with the addition of the extract and the assay mixture was then read in a spectrophotometer at $340 \mathrm{~nm}$. The second reading was performed $10 \mathrm{~min}$ after the beginning of the reaction while temperature was maintained at $30^{\circ} \mathrm{C}$ during this interval. As before, all of the assays were carried out in triplicate. A blank control was performed omitting oxoglutarate. The GDH activity was expressed in nmol of NADH consumed per hour per gram fresh mass.

External leaf morphology: Eight V. gigantea plants cultivated in vitro and $3 \mathrm{~cm}$ in height were employed. Five leaves per plant were harvested for analysis of the trichomes and stomata densities. The apical and basal leaf regions sampled were approximately $1 \mathrm{~cm}$ long. The plant material was treated according to the maceration technique using hydrogen peroxide and acetic acid (Franklin, 1945), as described by Kraus and Arduin (1997). Surfaces were stained with $1 \%$ safranin, and microscope slides were assembled in 50\% glycerin. The counting of paired data in relation to trichomes and stomata was performed for both regions (top and base) and leaf faces (adaxial and abaxial) using the KS100 software version 3.0 (ZEISS, 1997) and a digital camera connected to a regular ZEISS optical microscope. Ten fields of $1 \mathrm{~mm}^{2}$ per leaf portion were counted from a total of 40 leaves.

Statistical analysis: All data were presented as mean values with standard errors. The differences between the densities of trichomes and stomata in apex and base regions of the bromeliad leaves were assessed by $t$ Student mean comparison test at $P<0.05$. The analysis of variance (ANOVA) and linear regression were performed using GraphPad Prisma V.4 Statistical Software (GraphPad software, 2003) and JMP 5.01 software (SAS Institute, 2002). The significant differences among the measurements of enzyme activities were contrasted by a TukeyKramer test at $P<0.05$.

\section{RESULTS AND DISCUSSION}

The activities of GS and NADH-GDH were always significantly higher in the apical portion than in the basal region of leaves at all harvest times (Figures 3 and 4). By contrast, on the abaxial side trichome density was higher in the basal section whereas stomatal density was higher on the apical section (Table 1, Figure 5A,C). A linear regression curve applied to data of stomata and trichome densities clearly indicates an inverse relationship of these two structures between the base and the apex of the leaf. In the apical portion, the density of trichomes was about $70 \%$ that of the base whereas the density of stomata in the apex was approximately double than that of the base. However, on the adaxial surface, no stomata were found and a greater concentration of trichomes was observed at the leaf base (Figures 6A,B).

The highest GS and GDH activities, detected in the upper portion of the leaves of $V$. gigantea, suggest that this region may be preferentially involved with nitrogen assimilation, while the basal portion may be involved with its absorption. A side experiment revealed a similar 


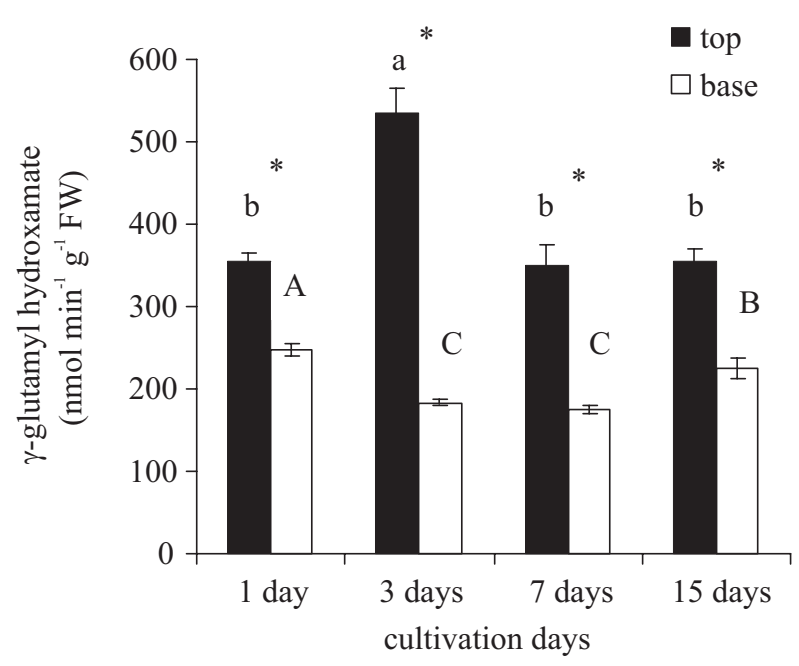

Figure 3. Activities of glutamine synthetase (GS) at apical and basal leaf portions of Vriesea gigantea plants after in vitro cultivation for $1,3,7$ and $15 \mathrm{~d}$ with $5 \mathrm{mM}$ urea. Asterisks indicate significant differences between means in relation to both leaf regions (top/base) for each day analyzed ( $t$-Student test; $P<0.05$ ). Different letters indicate means significantly different among cultivation days (Tukey-Kramer test; $P<0.05$ ). Capital letters correspond to basal portion and small letters to the apical portion of the leaf.

pattern for enzyme activity regardless of whether it was expressed on a fresh or dry mass basis (unpublished results). This is the first study to report that ammonium assimilation may take place preferentially in a specific portion of tank-forming bromeliad leaves. This hypothesis becomes more plausible when one considers the inverse correlation obtained for the densities of trichomes and stomata between these two portions of the leaf, suggesting that there exists a gradient of increasing trichome density and decreasing stomata from the apex to the base. Proença and Sajo (2004) also found an inverse correlation for these same parameters in several bromeliad species from the genus Aechmea. Barboza et al. (2006) reported a higher stomatal density at the upper and middle regions of leaves of pineapple cultivated for six months in a greenhouse.

It is relevant to suppose that the photosynthetic function is predominantly associated with the apical portion of tank bromeliad leaves, as this region is where the largest quantity of stomata was found. Moreover, this portion of the leaf receives a higher incidence of light

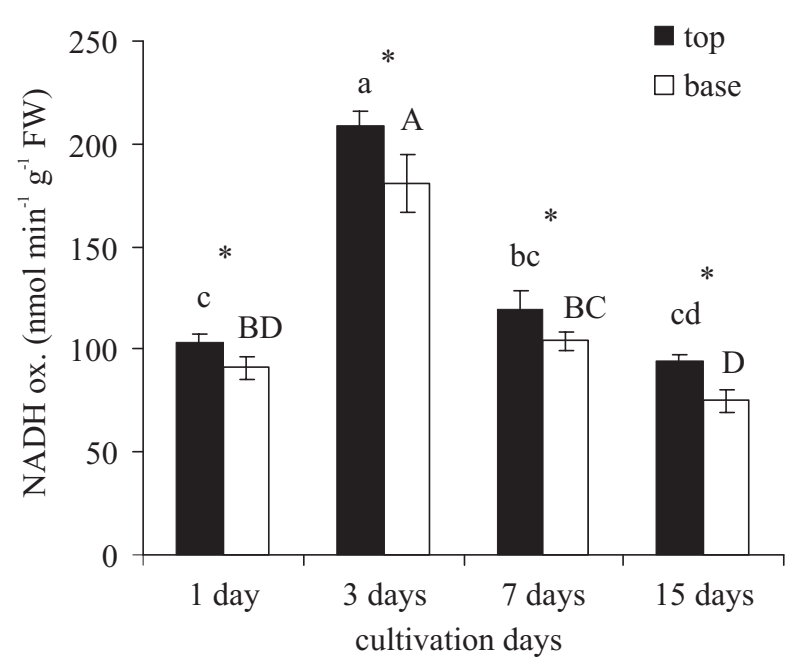

Figure 4. Activities of NADH-dependent glutamate dehydrogenase (NADH-GDH) at apical and basal leaf regions of Vriesea gigantea plants after in vitro cultivation for 1, 3, 7 and $15 \mathrm{~d}$ with $5 \mathrm{mM}$ urea. Statistics as in Figure 3.

Table 1. Mean densities of stomata and trichomes at apical and basal portions of abaxial and adaxial leaf faces of Vriesea gigantea plants cultivated in vitro. All means are significantly different between apical and basal regions ( $t$-Student test, $P<0.0001)$.

\begin{tabular}{llcc}
\hline \multirow{2}{*}{ Leaf face } & \multirow{2}{*}{ Structure } & \multicolumn{2}{c}{ Density $\left(\right.$ number $\left.\mathrm{mm}^{-2}\right) \pm \mathrm{SD}$} \\
\cline { 3 - 4 } & & Top & Base \\
\hline Abaxial & stomata & $26.9 \pm 5.3$ & $15.7 \pm 7.8$ \\
Abaxial & trichomes & $25.8 \pm 7.3$ & $37.3 \pm 10.5$ \\
Adaxial & trichomes & $23.8 \pm 7.4$ & $42.6 \pm 13.8$ \\
\hline
\end{tabular}

since the tank formation impairs the incidence of irradiance at the overlapping regions of the leaves. Therefore, it is to be expected that the availabilities of ATP, electron transfer agents (NADH, NADPH, Fd) or carbon skeletons would be higher at the apical portion of bromeliad leaves, where they can be used, in part, in nitrogen assimilation. Popp et al. (2003) showed that there is an increase of carbohydrate and organic solute (malate, citrate) concentrations from the basal region to the top of the leaves of A. comosus. Olivares and Medina (1990), who also obtained similar results for leaves of Fourcroya humboldtiana, inferred that this physiological gradient was possibly the result of a light intensity gradient that formed at the diverse leaf regions when in 


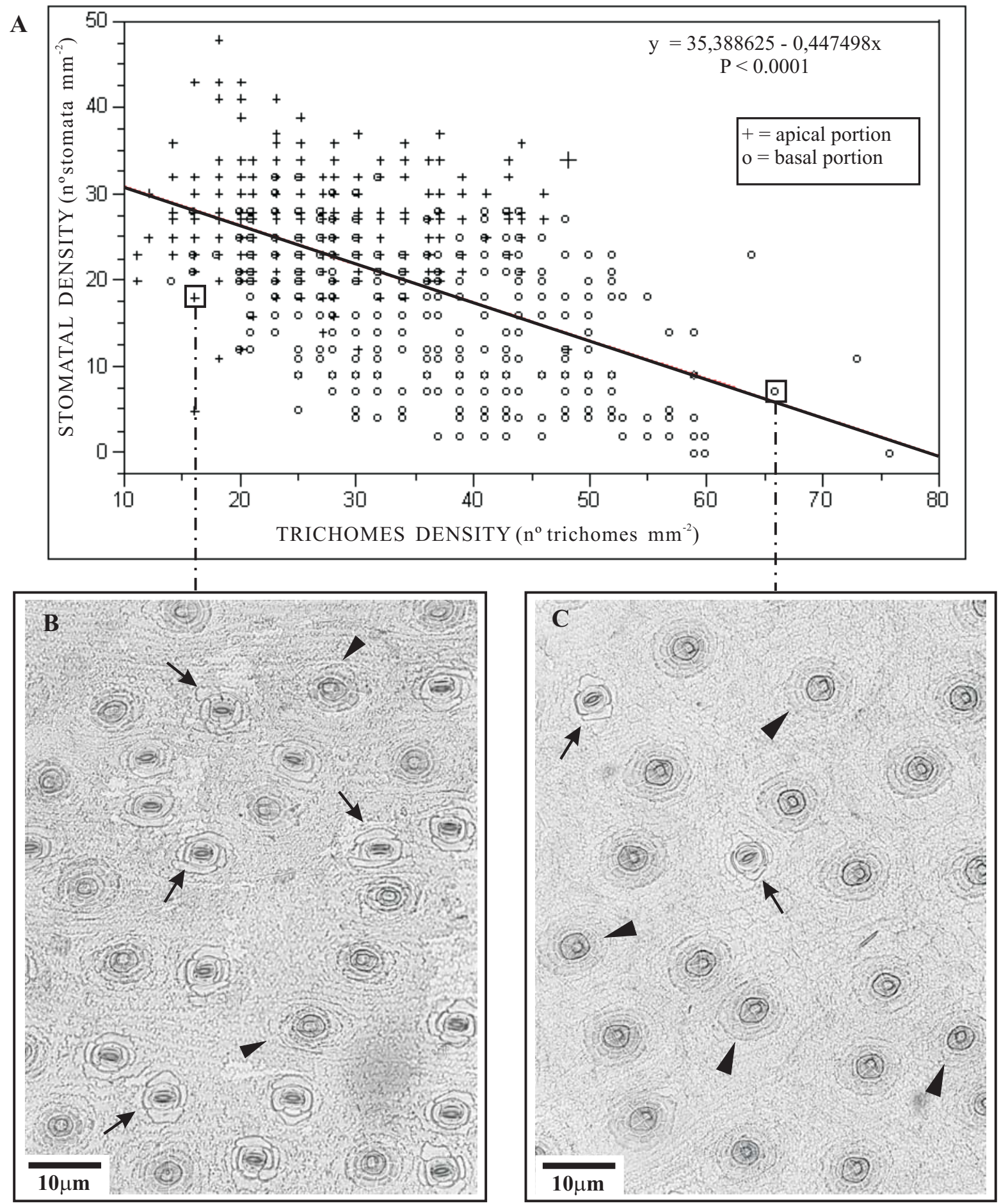

Figure 5. Densities of stomata and trichomes at the apical portion (+) and the basal portion (o) of the abaxial leaf face of Vriesea gigantea plants cultivated in vitro $(\mathbf{A})$ and front view of the abaxial epidermis at the apical (B) and basal (C) leaf portions of the $V$. gigantea plants, respectively. Examples of stomata and trichomes are indicated by arrows and arrowheads, respectively. 

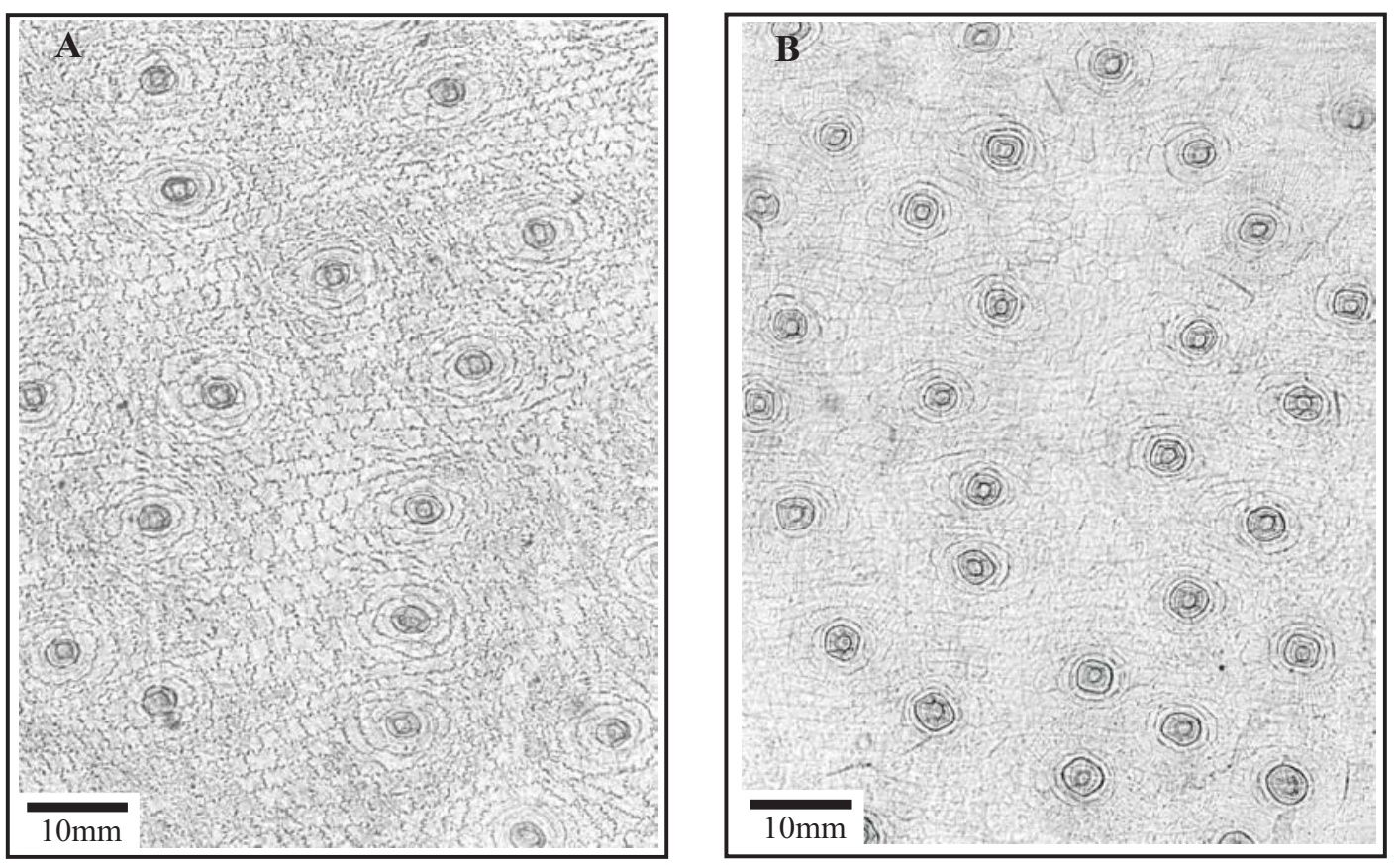

Figure 6. Front view of the adaxial epidermis showing the occurrence of trichomes at the apical (A) and basal (B) leaf regions of Vriesea gigantea plants cultivated in vitro. Stomata were not detected on the adaxial face.

rosette arrangement. The analyses of sun and shade leaves of CAM pineapple cultivars showed that within a leaf the chlorophyll-containing tissues have slightly more negative values for the carbon isotope composition ratio $\left({ }^{13} \mathrm{C} /{ }^{12} \mathrm{C}\right)$ than the non-chlorophyllous leaf bases, suggesting that carbohydrates were translocated to nonphotosynthetic tissues (leaf bases and stems) (Medina et al., 1994).

On the third day of in vitro cultivation of $V$. gigantea, a higher GS activity at the apical region was observed (Figure 3), which was about three times higher than that found for the basal region. The NADH-GDH activity presented higher values for both leaf regions on the third day of cultivation, approximately the double that of the first day (Figure 4). Some previous experiments conducted with $V$. gigantea under the same experimental conditions as in this study showed that the endogenous urea contents in the leaf tissues reached maximum levels within a period shorter than 1 day and progressively decreased on the subsequent days (C.A. Cambuí, unpublished results). Thus, increases in the activities of the enzymes GS and GDH verified between the first and the third days at the apical leaf region allow us to infer that, after being absorbed and hydrolyzed by urease, urea might generate an increase in the endogenous ammonium content within this period, the assimilation of which seems to occur by means of these two enzymes. The significant increase in NADH-GDH activity obtained for the basal portion of leaves of $V$. gigantea on the third day (Figure 4) may be associated with the protection of cells against the toxic effects generated by higher endogenous ammonium concentrations, since lower GS activities at the leaf base occur between the $3^{\text {rd }}$ and the $7^{\text {th }}$ day (Figure 3 ). Thus, the enzyme GDH could be acting in this region, preferentially promoting ammonium assimilation. Tamaki and Mercier (2001) showed that the activity of the enzyme NADH-GDH increased significantly in leaves of Tillandsia pohliana, an atmospheric epiphytic bromeliad, when exposed to high concentrations of $\mathrm{NH}_{3}$. However, we cannot exclude the possibility that the activity of GDH could have increased on the $3^{\text {rd }}$ day in the apical portion of leaves of $V$. gigantea due to the need to increase the availability of carbon skeletons for ammonium assimilation via GS/GOGAT since GDH may play an important role by interconnecting the metabolisms of carbon and nitrogen (Stitt et al., 2002). 
Acknowledgments: We are gratefully to the Fundação de Amparo à Pesquisa do Estado de São Paulo (FAPESP) for the fellowship (grant 03/13198-1) granted to the first author; to the Conselho Nacional de Desenvolvimento Científico e Tecnológico (CNPq) for the fellowships granted to the other two authors (grants 303715/2004/9 and 303319/2003-8).

\section{REFERENCES}

Barboza SBSC, Graciano-Ribeiro D, Teixeira JB, Portes TA, Souza LAC (2006) Anatomia foliar de plantas micropropagadas de abacaxi. Pesq. Agropec. Bras. 41:185-194.

Benzing DH (1990) Vascular Epiphytes. Cambridge University Press, Cambridge.

Cammaerts D, Jacobs M (1985) A study of the role of glutamate dehydrogenase in the nitrogen metabolism in Arabidopsis thaliana. Planta 163:517-526.

Endres L, Mercier H (2001a) Influence of nitrogen forms on the growth and nitrogen metabolism of bromeliads. J. Plant Nutr. 24:29-42.

Endres L, Mercier H (2001b) Ammonium and urea as nitrogen sources for bromeliads. J. Plant Physiol. 158:205-212.

Farnden KJS, Robertson JG (1980) Methods for studying enzymes involved in metabolism related to nitrogenase. In: Bergsen FJ (ed), Methods for Evaluating Biological Nitrogen Fixation, pp.279-286. John Wiley \& Sons, Chichester.

Franklin GL (1945) Preparation of thin sections of synthetic resins and wood-resin composites, and a new macerating method for wood. Nature 155:51

Knudson L (1946) A new nutrient solution for germination of orchid seed. Am. Orch. Soc. Bull. 15:214-217.

Kraus JE, Arduin M (1997) Manual Básico de Métodos em Morfologia Vegetal. Editora Universidade Rural (EDUR), Rio de Janeiro.

Leme EMC, Marigo LC (1993) Bromélias na Natureza. Marigo Comunicação Visual, Rio de Janeiro.

Marschner H (1995) Mineral Nutrition of Higher Plants. $2^{\text {nd }}$ ed. Academic Press, London.

Medina E, Ziegler H, Lüttge U, Trimborn P, Francisco M (1994) Light conditions during growth as revealed by $\delta^{13} \mathrm{C}$ values of leaves of primitive cultivars of Ananas comosus, an obligate CAM species. Funct. Ecol. 8:298-305.

Mercier H, Kerbauy GB, Carvalho MTV, Derbyshire E (1997) Growth and GDH and AAT isoenzyme patterns in terrestrial and epiphytic bromeliads as influenced by nitrogen source. Selbyana 18:89-94.
Mercier H, Nievola CC (2003) Obtenção de bromélias in vitro como estratégia de preservação. Vidalia 1:57-62.

Miflin BJ, Habash DZ (2002) The role of glutamine synthetase and glutamate dehydrogenase in nitrogen assimilation and possibilities for improvement in the nitrogen utilization of crops. J. Exp. Bot. 53:979-987.

Murashige T, Skoog F (1962) A revised medium for rapid growth and bioassays with tobacco tissue culture. Physiol. Plant. 15:473-479.

Nievola CC, Mercier H, Majerowicz N (2001) Uréia: uma possível fonte de nitrogênio orgânico para as bromélias com tanque. Bromélia 3:44-48.

Olivares E, Medina E (1990) Carbon dioxide exchange, soluble carbohydrates and acid accumulation in a fructan accumulating plant: Fourcroya humboldtiana Treal. J. Exp. Bot. 41:579-585.

Padilha V (1973) Bromeliads. Crow Publishers, New York.

Pérez-Soba M, Stulen I, van der Eerden LJM (1994) Effect of atmospheric ammonia on the nitrogen metabolism of Scots pine (Pinus sylvestris) needles. Physiol. Plant. 90:629-636.

Popp M, Janett HP, Lüttge U, Medina E (2003) Metabolite gradients and carbohydrate translocation in rosette leaves of CAM and C3 bromeliads. New Phytol. 157:649-656.

Proença SL, Sajo MG (2004) Estrutura foliar de espécies de Aechmea Ruiz \& Pav. (Bromeliaceae) do Estado de São Paulo, Brasil. Acta Bot. Bras. 18:319-331.

Sakai WS, Sandford WG (1980) Ultrastructure of the water-absorbing trichomes of pineapple (Ananas comosus, Bromeliaceae). Ann. Bot. 46:7-11.

Salama AMSEl-DA, Wareing PF (1979) Effects of mineral nutrition on endogenous cytokinins in plants of sunflower (Helianthus annuus L.). J. Exp. Bot. 30:971-981.

SAS Institute Inc (2002) JMP - Statistical Discovery Software. Version 5.01. Cary, NC, USA.

Stitt M, Müller C, Matt P, Gibon Y, Carillo P, Morcuende R, Scheible W-R, Krapp A (2002) Steps towards an integrated view of nitrogen metabolism. J. Exp. Bot. 53:959-970.

Tamaki V, Mercier H (2001) Effects of different ammoniacal nitrogen sources on $\mathrm{N}$-metabolism of the atmospheric bromeliad Tillandsia pohliana Mez. Rev. Bras. Bot. 24:407-413.

Tercé-Laforgue T, Mäck G, Hirel B (2004) New insights towards the function of glutamate dehydrogenase revealed during source-sink transition of tobacco (Nicotiana tabacum) plants grown under different nitrogen regimes. Physiol. Plant. 120:220-228. 